Lutz, A.- 09. Memorias do Institute Oswald Cruzo. Tomo I, Faciculo II, pp. 124-146.

Lutz And Splendore.-'04. Centralblatt für Bakteriologie, Bd. 42. Id., '08. Centralblatt für Bakteriologie Bd 46, pp 311-315.

Strickland, E. H.-'11. Biological Bulletin, Vol. 21, pp. 302338. Id., '13. Journal of Morphology. Vol. 24, pp. 43-105.

\title{
NOTES ON SOME SPECIES OF CECIDOMYIIDÆ.
}

BY WILLIAM BEUTENMULLER, NEW YORK.

Dasyneura hirtipes Osten-Sacken.

Cecidomyia hirtipes Osten-Sacken, Mon. Dipt. N. Am., Vol. I, 1862 , p. 195 ; Glover, MSS. Notes, Dipt. 1874 , p. 8; Bergenstamm and Loew. Verh. zool. bot. Gesell. Wien., Vol. XXVI, 1876, p. 47.

Dasyneura hirtipes Aldrich, Cat. N. Am. Dipt. 1905, p. 155.

Male and Female.-Head red, clothed with. red scales; antennæ brown. Neck red; thorax above, smooth, polished, blood-red, blackish above with a few erect brown hairs, pleura marked with black; scutellum red. Abdomen bright scarlet red with blackish appressed scales. Legs wholly black; coxæ reddish. Wings with a dense blackish pubescence. Halteres reddish or orange, the club black. Expanse 5.5-6 mm. Length 3.5-4 mm.

Gall.-Polythalamous, large bud-like and solid when immature, with a number of aborted leaves surrounding it. When mature, it is soft inside and filled with a white foam-like substance, in which are a number of long, narrow, larval cells. When the flies are ready to emerge, the gall bursts open and it is then of the appearance of a miniature cauliflower; the large white center surrounded by the dark green leaves, giving it the appearance of that plant. Diameter 50 to $25 \mathrm{~mm}$.

The gall is formed at the tip of stunted stalks of the fragrant golden-rod (Solidago graminifolia) in June and July. When old, the white foam-like internal substance decays and the gall is then hard, woody and hollow inside, with a large opening on top. It remains on the bushes in this state over winter. I have collected the gall of $C$. hirtipes at Fort Lee, New Jersey, late in June, from which the adults began to emerge on July 6 .

December, 1913 


\section{Dasyneura seminivora Beuten.}

Cecidomyia (?) seminivora, Beutenmuller, Bull. Am. Mus. Nat. Hist., Vol. XXIII, 1907, p. 390, pl. XV., figs. 1-4 (larva and gall).

Male and Female.-Head and antennæ black. Thorax deep brown-black, somewhat shining, with erect hairs in the grooves; scutellum deep red. Abdomen deep red, covered with deep brown black scales above; under side wholly deep red with rather long, erect, dark hairs. Legs blackish above, pale brown beneath. Wings blackish hyaline with bluish reflection; extreme base of wings red. Halteres yellowish brown. Expanse $4 \mathrm{~mm}$. Length $2 \mathrm{~mm}$.

This species was heretofore known from the larva and gall only, and the adults are here described for the first time. The flies emerged from May 31 to June 15 . The gall is a deformation of the seed-pods of certain species of violets.

\section{Lasioptera podagra, sp. nov.}

Male and Female.-Head clothed with gray scales in front and behind; eyes black; antennæ deep brown, first and second joints dull red. Thorax narrowly banded on each side from the anterior portion of the scutellum, with gray and brown hair-scales. Along the middle of the thorax is a very broad golden brown band from the scutellum to almost the anterior portion. Scutellum marked with gray scales. Abdomen velvety black, with a row of large, broad gray marks on each side, decreasing in size toward the last segment. Under side: Thorax black marked with gray, abdomen wholly gray; legs black above, white on the joints, tarsi banded with white; femora beneath white from the base to about the middle. Wings hyaline with black scales, red at the extreme base and with a very small white mark at the middle of the costa. Halteres red or white. Expanse $2.50 \mathrm{~mm}$. Length $1.50 \mathrm{~mm}$.

Gall.-Polythalamous, consisting of an elongate swelling enlargement of the stems of a species of aster. Length 20 to $50 \mathrm{~mm}$., Width 8 to $10 \mathrm{~mm}$.

Habitat: Fort Lee, New Jersey; Bronx Park, New York City (W.B.).

Types: Collection Am. Mus. Nat. Hist. 


\section{Lasiopiera linderce Beuten.}

Lasioptera (?) linderce Beutenmuller, Bull. Am. Mus. Nat. Hist., Vol. XXIII, 1907, p. 398, pl. XIV., fig. 3-6 (gall and larva). Male and Female.-Head black, face and posterior portion snowy white; antennæ black, first, second and third joints white. Thorax velvety black, broadly bordered with white around the anterior portion to the base of the wings. In the grooves are a few scattered pale brown hairs. Scutellum black, with a few long white hairs. Abdomen black, first segment white, second segment with a small white mark on the dorsum posteriorly, the two following segments each with a broad white band posteriorly, the remaining segments wholly black. Under side of abdomen broadly white. Legs pale brown or sordid white; tibiæ marked with black at the middle. Wings hyaline with black scales and a white mark at the middle of the costa and at the base of the wings. Halteres white. Expanse $3 \mathrm{~mm}$.

The adults are here described for the first time. They emerge from the galls in June.

\section{Lasioptera vernonice Beuten.}

Cecidomyia (?) vernonice Beutenmuller, Bull. Am. Mus. Nat. Hist., Vol. XXIII, 1907, p. 389, pl. XV., figs. 7-8.

Male and Female.-Head white in front, black posteriorly; antennæ black; first and second joints white. Thorax deep velvety black, with a very broad white margin around the anterior portion to the base of the wings. In the two grooves of the thorax are a few scattered, white hairs. Scutellum scaled with white and with a few long hairs of the same colour. Abdomen deep velvety black, each segment with a very narrow white band posteriorly and not extending to the extreme sides of the abdomen. Legs black, with the joints pure white; coxæ white. Under side of abdomen broadly white. Wings blackish hyaline, with a white mark at the middle on the costa. Halteres white. Expanse $3.5 \mathrm{~mm}$. Length 1.5 $\mathrm{mm}$.

Heretofore, this species was known only from the larva and gall.

Cecidomyia meibomice Beuten.

Cecidomyia (?) meibomice Beutenmuller, Bull. Am. Mus. Nat. Hist., Vol. XXIII, 1907, p. 390, pl. XV, figs. 9, 10, 11. 
Male and Female.-Eyes large, contiguous at the vertex, black; face semi-translucent, dull orange red. Antennæ yellowish brown with erect black hairs. Thorax dull, semi-translucent red, with rather long, blackish hairs in the grooves on top, forming two parallel lines, and a few hairs at the sides; scutellum dull semi-translucent red. Abdomen dull semi-translucent, orange red sparsely, with brown black hairs; tip of abdomen blunt. Under side of body dull red. Legs fuscous. Expanse $3.50 \mathrm{~mm}$. Length $1.33 \mathrm{~mm}$.

Since my description of the larva and galls of this species I succeeded in breeding the adults from galls collected in the Valley of the Black Mountains, North Carolina, in September 1906, and they are here characterized for the first time.

Cecidomyia clavula, sp. nov.

Female.-Head black, eyes large, contiguous, face pale orange; antennæ pale, semi-translucent, orange yellow, banded with black, hairs gray. Thorax above semi-translucent orange, tinged with red; underside orange. Abdomen orange, with yellow hairs. Legs white, with deep black bands. Wings hyaline yellow, with metallic blue and purplish reflections; a broad, dusky grayish, wavy transverse band a little beyond the middle, followed by a similar close to the outer margin; on the outer margin is a grayish patch almost connected with the preceding transverse band; costa yellow, deep black below the apex; fringes yellow. Halteres semi-translucent orange. Length $2 \mathrm{~mm}$. Expanse $4 \mathrm{~mm}$.

Very closely allied to Cecidomyia variegata of Europe. Bred from enlargements of the terminal twigs of Dogwood (Cornus florida). It is the gall described by me in the Bulletin Am. Mus. Nat. Hist., Vol. IV, 1892, p. 269.

\section{Rhopalomyia remuscula Beuten.}

Cecidomyia (?) remuscula Beutenmuller, Bull. Am. Mus. Nat. Hist., Vol. XXIII, 1907, p. 392, pl. XVII, figs. 7, 8.

Male.-Head black; antennæ fuscous. Thorax shining black above, with two pale, parallel ${ }^{*}$ lines dorsally, pleura yellowish brown; scutellum yellowish. Abdomen dull yellowish, covered with brown hairs. Wings blackish, hyaline. Halteres yellowish, knobs black. Legs fuscous. Length $2 \mathrm{~mm}$.

Hitherto known only from the gall and the larva. 


\section{$2 \mathrm{BHL}$ Biodiversity Heritage Library}

1913. "Notes on some species of Cecidomyiidae." The Canadian entomologist 45, 413-416. https://doi.org/10.4039/Ent45413-12.

View This Item Online: https://www.biodiversitylibrary.org/item/22231

DOI: https://doi.org/10.4039/Ent45413-12

Permalink: https://www.biodiversitylibrary.org/partpdf/27108

\section{Holding Institution}

MBLWHOI Library

\section{Sponsored by}

MBLWHOI Library

\section{Copyright \& Reuse}

Copyright Status: NOT_IN_COPYRIGHT

This document was created from content at the Biodiversity Heritage Library, the world's largest open access digital library for biodiversity literature and archives. Visit BHL at https://www.biodiversitylibrary.org. 